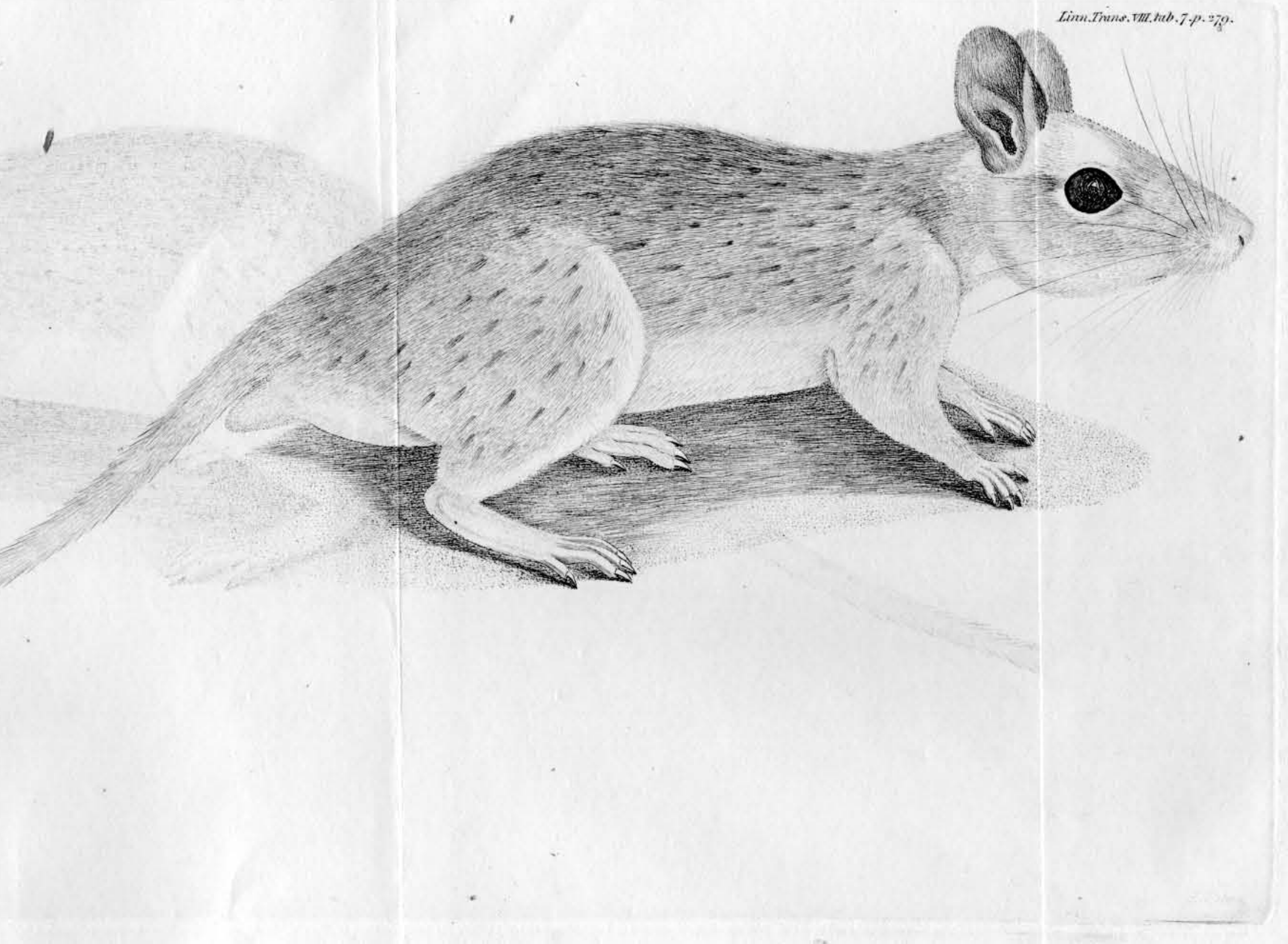


IX. Description of a Species of Jerboa, found in the upper Provinces of Hindustan, between Benares and Hurdwar. By Lieut. Col. Thomas Hardwicke, F.L.S.

Read December 18, 1804.

Dipus indicus.

Dıpus palmis tetradactylis, plantis pentadactylis, caudâ elongatâ apice floccosâ fuscâ, corpore fulvo lineolis fuscis.

\section{TAB. VII.}

The provincial name of this animal is Hereena-moos, alluding to its colour, which is that of the common antelope, so numerous on the plains of Hindustan, and there called Hereen. Moos is the name for a rat.

It is about the size of the common house-rat; its head large in proportion to the body; ears large, rounded, erect, naked, or very obscurely hairy; nose much rounded, furnished with numerous long fine hairs or whiskers; the upper jaw longer by half an inch than the lower; upper lip slit. In each jaw are two incisores; those of the lower twice the length of the upper ones, which are broader, and longitudinally furrowed. Lyes large and of a shining black; legs unequal in length; the fore legs onethird shorter than the hind ones, with four toes forward, and a small tubercle in the place of a thumb. On the hind feet five toes, the three middle ones twice the length of those of the fore feet; the exterior latefal toe hardly half the length of the mid- 
dle ones; and the interior toe still shorter. The nails or claws slender, awl-shaped, white; the feet thinly covered with soft hair. Length of the animal from nose to tail six inches and an half; length of the tail seven inches, its form cylindrical, but tapering, thinly covered with short hair to within the last two inches, and ending with a compressed tuft of long dark brown soft hair. The prevailing colour is a bright bay, mixed on the upper parts of the body with pencil-like strokes of darkbrown, longitudinally disposed; the head is of a lighter colour, particularly about the eye and lower parts of the cheeks; all the under parts are white, and the hair at the roots of a soft, silky wature, and ash-coloured.

In weight this animal seldom exceeds five ounces. The figure accompanying this paper is the natyral size of a nale subject, which weighed 4 ounces 12 drachms, avoirdupoise.

These animals are yery numerous about cultivated lands, and particularly destructive to wheat and barloy crops, of which they lay up considerable hoards, in spacious burrows, near the sccnes of their plunder. They cut the culms of the ripening corn just beneath the ears, and convey them thus entire to one common subterraneous repository, which, when filled, they carefully close, and do not open for use till supplies abroad become distant and scarce. Grain of all kinds is their favourite food; but, in default of this, they have recourse to the roots of grass and other vegetables. Ahout the close of day, they issue from their burrows, and traverse the plains in all directions, to a considerable distance; they run fast, but oftener leap, making bounds of four or five yards at a time, carrying the tail extended in a horizuntal direction. When eating, they sit on their bind legs like a squirrel, holding the food between their fore feet. They never appear by day, neither do they commit depredations within doors. I 
have observed their manners by night, in moonlight nights, taking my station on a plain, and remaining for some time with as little motion as possible. I was soon surrounded by hundreds at the distance of a few yards; but on rising from my seat, the whole disappeared in an instant, nor did they venture forth again for ten minutes after, and then with much caution and circumspection.

A tribe of low Hindus, called Kunjers, whose occupation is hunting, go in quest of these animals at proper seasons, to plunder their hoards of grain; and often, within the space of twenty yards square, find as much corn in the ear as could be crammed into a common bushel. 'They inhabit dry situations, and are often found at the distance of some miles out of the reach of water to drink. In confinement this animal soon becomes reconciled to its situation, and docile; sleeps much in the day, but when awake feeds as freely as by night. The Hindus above mentioned esteem them good and nutritious food. 